Organo- and

\title{
Enantioselective Organocatalysis Using SOMO Activation
}

Key words

somo activation

allylic alkylation

enantioselectivity<smiles>O=CCP</smiles><smiles>[R]C1NC(PC)C([N+](=O)[O-])N1CC</smiles><smiles>c1ccccc1</smiles><smiles>[R7]C=CN1C(=O)C([R7])N([N+](=O)[O-])C1P</smiles>

1-electron oxidation

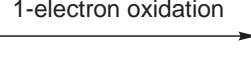<smiles>O=CCP</smiles><smiles>[R]C(=C)C[AsH3]</smiles>

$\mathrm{R}^{1}=$ Alk

$\mathrm{R}^{2}=\mathrm{Ar}$, Alk

Selected examples:<smiles>CCCC(C)C=O</smiles><smiles>C=CCC(C=O)C1CCCCC1</smiles><smiles>C=C(P)CC([18OH])C=O</smiles>
$72-88 \%$ yield er $=93: 7$ to $98: 2$

DME, $-20^{\circ} \mathrm{C}, 24 \mathrm{~h}$

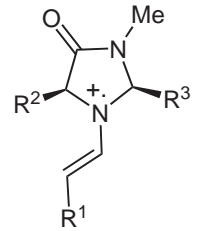

SOMO-activated

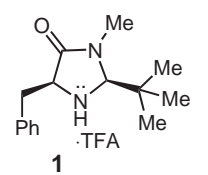

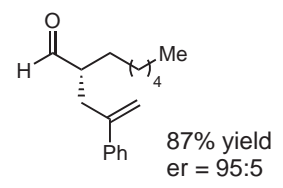

Heteroarylation:

Cyclization/halogenation cascade:
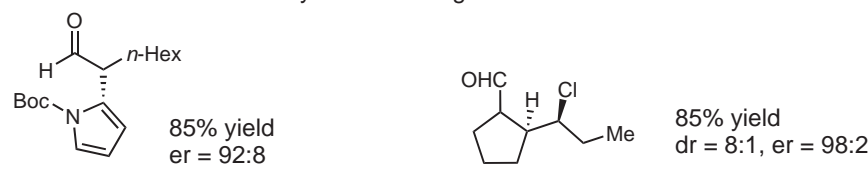

Significance: The authors report a direct enantioselective allylic alkylation of aldehydes using SOMO activation. They recognized that a one-electron oxidation of a transient enamine species would generate a $3 \pi$-electron radical cation with a singly occupied molecular orbital (SOMO) that is activated to a variety of $\pi$-rich nucleophiles. Imidazolidinium salt 1 was found to be the best catalyst and ceric ammonium nitrate (CAN) was used as the stoichiometric oxidant for the allylic alkylation of different aldehydes. With 20 mol\% of the catalyst 1 and two equivalents of CAN, good to high yields (72-88\%) and high enantioselectivities (ee = 93:7 to 98:2) are obtained for a variety of allylsilanes.
Comment: Sibi and Hasegawa have independently developed an enantioselective $\alpha$-oxygenation of aldehydes using SOMO activation (J. Am. Chem. Soc. 2007, 129, 4124-4125; see also: Synfacts 2007, 654). In contrast to the authors' stoichiometric use of CAN, they used substoichiometric amounts of $\mathrm{FeCl}_{3}$ with $\mathrm{NaNO}_{2}-\mathrm{O}_{2}$ as the co-oxidant. The concept of SOMO activation in catalysis, as invented by these two groups, will certainly expand the scope of asymmetric transformations in organic synthesis. In this paper the authors have also described preliminary reports for enantioselective heteroarylations and cyclization-halogenation cascade processes. 